\title{
Mesothelioma in Cyprus: the role of tremolite
}

\author{
K McCONNOCHIE, L SIMONATO, P MAVRIDES, P CHRISTOFIDES, \\ F D POOLEY, J C WAGNER
}

From the Department of Tuberculosis and Chest Diseases and MRC Team on Occupational Lung Diseases, University of Wales College of Medicine, Llandough Hospital, Penarth, South Glamorgan, Wales, Unit of Analytical Epidemiology, Division of Epidemiology and Biostatistics, International Agency for Research on Cancer, Lyon, France, The Chest Clinic, Nicosia General Hospital, Nicosia, Cyprus, Institute of Materials, University College, Cardiff, Wales

ABSTRACT There is a chrysotile mine in the central mountains of Cyprus but no other appreciable $\stackrel{\vec{\omega}}{\mathrm{N}}$ source of industrial asbestos. Hence the island was thought to offer ideal conditions to seek pure 음 chrysotile induced mesothelioma. The first reported case was a village woman whose lung tissue $\vec{\neg}$ contained amphibole asbestos fibres, which were later identified as tremolite. This began a search for the origin of her exposure to asbestos. Our studies have shown that tremolite is widespread, being found, along with chrysotile, in domestic and environmental dust samples. Other cases of $\vec{\bullet}$ mesothelioma have been diagnosed, and the pattern of their distribution suggests that the mine is not the major source of disease. Exposure to tremolite is equally, if not more, important.

The association between inhalation of asbestos fibres and mesothelioma was firmly established in the 1960s, but it is still uncertain which types of asbestos are responsible. There is little doubt about crocidolite being responsible ${ }^{12}$ but the case for chrysotile, the only serpentine asbestos, is not so well proven. Crocidolite is not the only amphibole asbestos. Amosite, which has been commercially exploited, is also known to cause mesothelioma. ${ }^{3}$ Tremolite, actinolite, and anthophyllite, which also belong to this group, occur in a wide range of geological environments but do not have the same commercial applications, and knowledge of their effect on human lung is still scarce.

To obtain information about the effect of one particular type of asbestos it would seem logical to study a population most likely to have had a pure exposure. The island of Cyprus, with a large chrysotile mine in the central mountains and no other appreciable source of asbestos, seemed to offer an ideal opportunity to study such a population. Mining activity started in the area several centuries ago. The chrysotile present is low grade and all mining operations are performed in the open air. The workforce,

Address for reprint requests: Dr K McConnochie, Department of Tuberculosis and Chest Diseases, University of Wales College of Medicine, Llandough Hospital, Penarth, South Glamorgan, Wales, CF6 IXX, United Kingdom.

Accepted 24 November 1986 which numbered about 5000 in the 1930s, many of whom lived in specially constructed villages just $\mathbb{\perp}$ above the mine, has decreased to about 350 in the 1980 s.

In 1966 contact was made between the Medical Research Council Pneumoconiosis Unit, Penarth, and chest physicians in Nicosia. In 1969, as a result of their collaboration, a pleural biopsy specimen from an elderly woman was examined, which showed the histological features of diffuse mesothelioma. This woman had never been a mine worker but resided in 3 a village nearby. Attached to her pleural biopsy specimen was a fragment of lung in which unexpected amphibole asbestos bodies were found. These were later identified as tremolite fibres (fig 1).

Thus the original premise that Cyprus had only chrysotile asbestos seemed to be wrong. Further work was needed to look at both industrial and environ- os mental sources of asbestos and to identify fibre types. $N$ In this study we have examined human and sheep N lung samples, environmental dust samples, and case records.

\section{Patients and methods}

\section{CASES}

Certification that death was due to natural causes can be performed by various responsible people in a $\frac{\rho}{\mathbb{D}}$ village. No central record is kept. Details of $\varrho$ occupational and residential histories were obtained from the case records of those who have sought medi- 


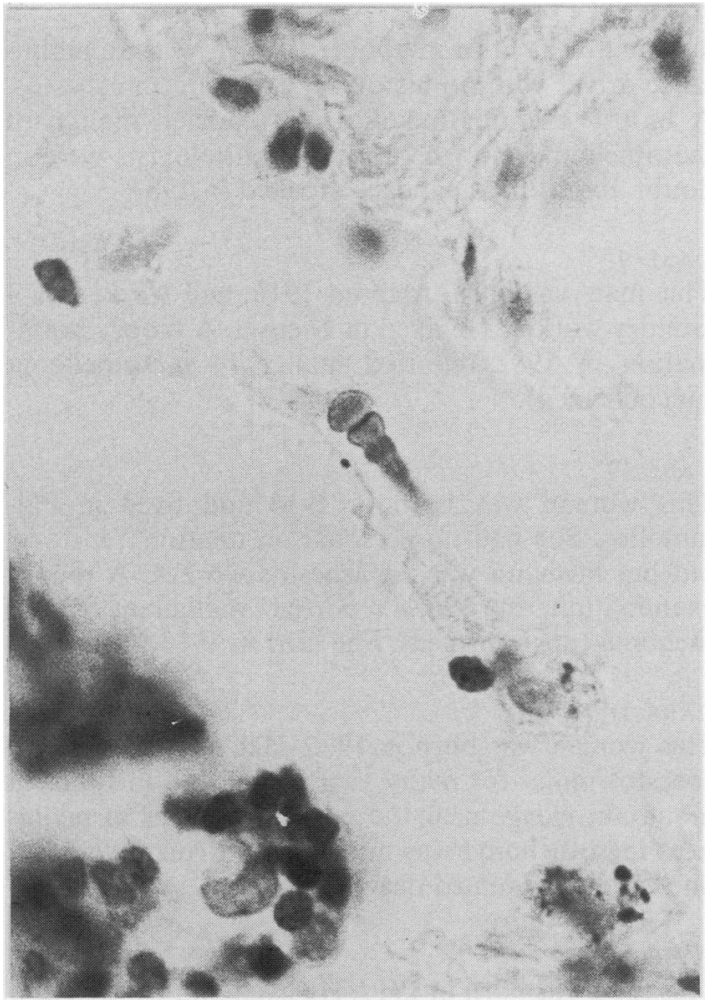

Fig 1 Amphibole asbestos body found in lung tissue of a woman resident (case 2 ).

cal attention. Confirmation of the diagnosis in over half of these cases was made by a panel of pathologists who served on the advisory committee on asbestos to the International Agency for Research on Cancer.

\section{FIBRE ANALYSIS}

Fibres were obtained from three sources: (a) human lung tissue; (b) sheep lung tissue; (c) environmental samples. Lung tissue samples were digested in the usual fashion ${ }^{4}$ and fibre analysis performed using an analytical transmission electron microscope.

Six samples of sheep lung were taken from animals known to have grazed for several years in the area around the mine. Specimens were coded, then mixed with similar material from other sources so that the examining microscopist was unaware of their origin.

Environmental samples were obtained from various places. Within the mine, dust was collected from the top of dividing partitions in the office block. Dust was also collected from rafters of the roof eaves of houses in Amiandos and Pelendria, two villages close to the mine. Riverbeds in this region dry up in the summer months, allowing the collection of residue.
Specimens were taken from the Kouris river, which flows through the mining area, the Limnatis river, which flows east of the Kouris, and the estuary where they jointly flow into Episkopi Bay (fig 2).

\section{Results}

CASE 1

This man was born in 1904. Between 1918 and 1940 he worked as an asbestos miner, and then between 1940 and 1952 he had various other jobs, details of which were not known. From 1952 until 1968 he worked in the mine as a plumber and assistant mechanic. In 1966 a pleural biopsy specimen was suggestive of mesothelioma but the majority diagnosis from a panel of pathologists was non-specific pleural fibrosis. The biopsy examination had been performed because of "pleural reaction" followed by pleural effusion. The patient survived until 1980, when the final diagnosis was confirmed, by the same panel, as malignant mesothelioma. Fibre content of the lung showed a relevant presence of tremolite (table 1).

CASE 2

This woman was born in 1908 in Zoopiyi. She had no history of occupational exposure. From 1948 to 1955

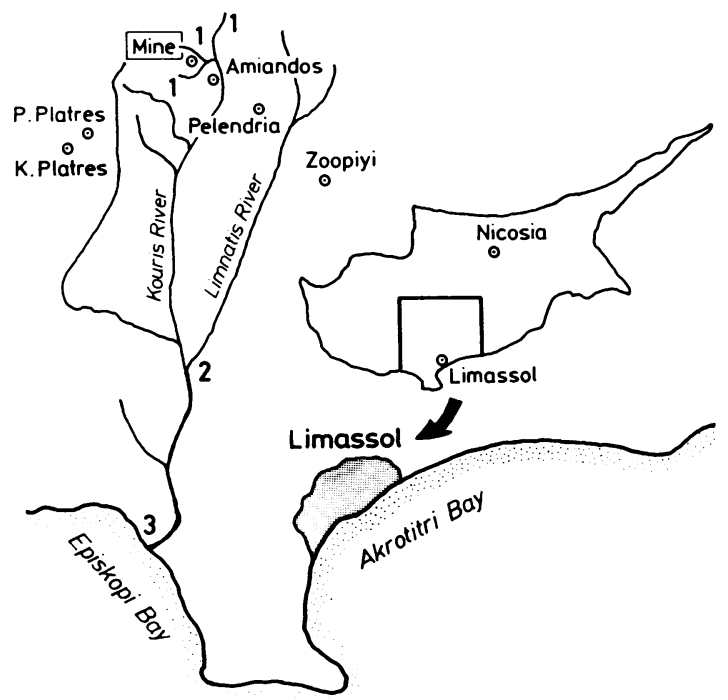

Fig 2 Analysis of riverbed samples collected during the dry summer months from three sites. (1) Denotes chrysotile and antigorite found; (2) denotes chrysotile, quartz, and tremolite found; and (3) denotes chrysotile, antigorite, and tremolite found. 
she lived in the district of Amiandos close to the mine. She died in 1969. The final diagnosis was malignant mesothelioma (confirmed). A fragment of lung showed the presence of tremolite.

\section{CASE 3}

This woman was born in about 1922 and had no personal occupational exposure, but her husband worked at the mine and she handled his dusty clothes. They lived in Amiandos. In 1972 she had a biopsy examination, which was suggestive of malignant mesothelioma (confirmed). She had since died.

\section{CASE 4}

This man was born in 1914 in Pelendria. Between 1927 and 1944 he worked as a labourer in the asbestos mine and later became a foreman excavator. Between 1944 and 1950 he was on military service, but from then until 1962 he was in charge of blasting at the mine, which involved using explosives in the rock wall. From 1962 to 1972 he worked in the mill. In 1972 a biopsy examination reported malignant mesothelioma (confirmed). He died in 1973.

\section{CASE 5}

This man was born in about 1930 in Pelendria. Between 1946 and 1950 he worked as a quarry labourer in the asbestos mine. From 1950 to 1958 he was a mason. Between 1959 and 1975 he was employed at the mine as an automobile greaser and mechanic. A biopsy examination in 1975 reported malignant mesothelioma (confirmed). He died in 1980 .

\section{CASE 6}

This man was born in 1907 in Pelendria. He spent his whole working life (1928-71) as an asbestos miner. A biopsy examination in 1978 reported malignant mesothelioma (confirmed). He died in 1979.

\section{CASE 7}

This man was born in about 1922 and lived in Nicosia. His occupational history was not known but there was a definite record that he had no history of exposure to asbestos. A biopsy examination in 1982 reported malignant mesothelioma (confirmed). He died in 1983.

\section{CASE 8}

This man was born in about 1926 . He was an ambulance driver with no history of exposure to asbestos. A biopsy examination in 1982 reported malignant mesothelioma, but the panel of pathologists were in doubt about the diagnosis. He died in 1983.

\section{CASE 9}

This man was born in about 1916, and worked as a laundry worker. He lived in Nicosia. A biopsy examination in 1982 reported malignant mesothelioma (unconfirmed).

\section{CASE 10}

This woman was born in 1914 and lived in Palinomilos. She had no personal occupational history, but her husband was an asbestos worker. A biopsy examination in 1982 reported malignant mesothelioma (unconfirmed). She died in 1983.

\section{CASE 11}

This woman was born in 1906 . Her husband was an asbestos miner for many years. She lived in Ikkos, a mountain village near the mine. Diagnosis of malignant mesothelioma was made in 1981 (unconfirmed). She is now presumed dead.

\section{CASE 12}

This man was born in 1917. He lived and worked as a farmer in Kellaki, a mountain village near the mine. Diagnosis of malignant mesothelioma was made in 1982 (unconfirmed). He died in 1983.

\section{CASE 13}

This man was born in 1922 . He had been an asbestos miner for 10 years. Diagnosis of malignant mesothelioma was made in 1982 (unconfirmed). He died in 1983.

\section{CASE 14}

This man was born in 1925 and was a South African who lived in the Transvaal. He had worked as a supermarket employee. Diagnosis of malignant mesothelioma was made in 1981.

No further cases have been reported to date (March 1986).

Table 1 Fibre analysis of human lung tissue

\begin{tabular}{|c|c|c|c|c|c|}
\hline \multirow[b]{2}{*}{ Diagnosis } & \multirow[b]{2}{*}{ Dry weight (mg) } & \multicolumn{4}{|c|}{ No of fibres $/ g \times 10^{6}$} \\
\hline & & Chrysotile & Tremolite & Amosite & Rutile \\
\hline $\begin{array}{l}\text { Mesothelioma } \\
\text { (Case 1) } \\
\text { Asbestosis }\end{array}$ & $\begin{array}{l}20 \\
25\end{array}$ & $\begin{array}{l}115 \\
175\end{array}$ & $\begin{array}{r}220.5 \\
37.6\end{array}$ & $\begin{array}{l}0 \\
0.9\end{array}$ & $\begin{array}{l}2 \cdot 4 \\
0\end{array}$ \\
\hline
\end{tabular}


Table 2 Fibre analysis of sheep lung tissue

\begin{tabular}{lllll}
\hline & & \multicolumn{2}{l}{ No of fibres $/ \mathrm{g} \times 10^{6}$} & \\
\cline { 2 - 5 } Sheep lung & Dry weight $(\mathrm{mg})$ & Chrysotile & Tremolite & Crocidolite \\
\hline 1 & 115 & 39.7 & 0.02 & 0.02 \\
2 & 169 & 7.8 & 0.56 & 0.07 \\
3 & 143 & 75.7 & 0.33 & 0.49 \\
4 & 91 & 26.5 & 7.00 & 0.52 \\
5 & 102 & 25.2 & 0.59 & 0.19 \\
6 & 125 & & & \\
\hline
\end{tabular}

\section{FIBRE ANALYSIS}

Tremolite, chrysotile, and crocidolite were found in varying amounts in human lung samples (table 1) and in sheep lung samples (table 2). Samples of human lung suitable for mineralogical analysis are difficult to obtain so we have compared the fibre count from lung tissue of case 1, a man with mesothelioma, with the fibre count from lung tissue of a male Cypriot known to have asbestosis. This man worked as a quarry labourer in the asbestos mines from 1946 to 1957 , after which he was an employee in his village market until 1977. He returned to the mine as a labourer in 1978 and in due course his chest $x$ ray film was noted to be abnormal. The diagnosis was confirmed by lung biopsy examination.

Tremolite was also found in biopsy material from case 2 , but it was not possible to quantify this further.

Environmental samples from the mine contained chrysotile, as expected, and antigorite, a non-fibrous mineral. Samples from roof eaves in both villages, however, contained tremolite (table 3). Samples collected during the summer months from the dried up riverbeds (fig 2) contained chrysotile, antigorite, quartz, and tremolite.

\section{Discussion}

Tremolite is found world wide in a variety of phases from coarse flake to fine fibre but causes most concern in its fibrous forms. It has been found as a contaminant of chrysotile deposits in Canada ${ }^{5}$ and also in talc deposits in New York State. ${ }^{6}$

Pooley examined lung tissue from 20 cases of asbestosis from the Canadian chrysotile mining industry and found tremolite fibre in $11 .^{7}$ In seven cases there was more amphibole and other fibres than chrysotile. He suggested that there may be preferential accumulation of amphibole fibres in the lung after exposure to mixed dust clouds.

In a study of six Canadian chrysotile workers with mesothelioma Churg found more tremolite group amphiboles than chrysotile in their lungs, which he attributed to failure of chrysotile to accumulate in lung tissue. ${ }^{8}$ He suggested that tremolite group amphiboles may be important in the pathogenesis of mesothelioma.

There is experimental evidence that tremolite is carcinogenic, ${ }^{9}$ but with no published details of a population that has had pure tremolite exposure there is, as yet, no conclusive evidence that it causes mesothelioma in man.

The original premise of this study was that only exposure to chrysotile has occurred in Cyprus. Our studies have shown that tremolite, as well as chrysotile, has a wide distribution on the island. Inspection of government surveys from the 1950 s revealed that this was known in geological circles. ${ }^{10}$ In the chapter on Troodos, the mountain area that contains the

Table 3 Identity of fibrous particles detected in mineral samples and general dust deposits from the mine and nearby villages

\begin{tabular}{|c|c|c|c|}
\hline & Chrysotile & Antigorite & Tremolite \\
\hline $\begin{array}{l}\text { Samples from the mine }(1960 \mathrm{~s}) \text { : } \\
\text { Raw asbestos } \\
\text { Final product }\end{array}$ & $\begin{array}{l}\text { Present } \\
\text { Present }\end{array}$ & $\begin{array}{l}\text { Present } \\
\text { Absent }\end{array}$ & $\begin{array}{l}\text { Absent } \\
\text { Absent }\end{array}$ \\
\hline $\begin{array}{l}\text { Samples from the mine (1982): } \\
\text { Primary-mill } \\
\text { Grade 7-mill } \\
\text { Bagging-mill } \\
\text { Milling-mill } \\
\text { Final grit } \\
\text { General office dust }\end{array}$ & $\begin{array}{l}\text { Present } \\
\text { Present } \\
\text { Present } \\
\text { Present } \\
\text { Present } \\
\text { Present }\end{array}$ & $\begin{array}{l}\text { Present } \\
\text { Present } \\
\text { Present } \\
\text { Present } \\
\text { Present } \\
\text { Present }\end{array}$ & $\begin{array}{l}\text { Absent } \\
\text { Absent } \\
\text { Absent } \\
\text { Absent } \\
\text { Absent } \\
\text { Absent }\end{array}$ \\
\hline $\begin{array}{l}\text { Environmental samples from roof eaves (1982): } \\
\text { Kato Aminandos } \\
\text { Pelendria }\end{array}$ & $\begin{array}{l}\text { Present } \\
\text { Present }\end{array}$ & $\begin{array}{l}\text { Present } \\
\text { Present }\end{array}$ & $\begin{array}{l}\text { Present } \\
\text { Present }\end{array}$ \\
\hline
\end{tabular}


mine, there are descriptions of well exposed tremolite veins, particularly around Platres (fig 2). Distribution of these asbestos deposits is not homogeneous.

There are tremolite intrusions in the ore body of the mine. These fibres, regarded as contaminants, used to be separated from chrysotile in the crushing mill by "wind lifting" after the primary crushing. They were then blown away by the prevailing winds. In the 1970s this dust cloud of tremolite was to some extent controlled and fibres were no longer allowed to blow away freely. We found no tremolite in commercial samples from the 1960s or in samples taken from the mine more recently. This may reflect the uneven distribution of tremolite within the ore body and the efficacy of its separation from chrysotile.

Tremolite and chrysotile were found in all domestic dust samples (table 3 ) and in two of the random samples from the dry riverbeds (fig 2). No tremolite was found in the riverbed closest to the mine, but as a non-systematic sampling method was used this is probably not important.

The sheep studied had spent their lives grazing in an area within five miles of the mine and therefore acted as mobile air samplers. The difficulties of obtaining human lung for further study of environmental contamination made it necessary to use this alternative approach. Studies in Turkey have shown that the presence of fibres, in that case zeolite fibres, correlated with the geographical distribution of disease. ${ }^{11}$ The lungs of the Cyprus sheep contained tremolite and chrysotile. The low concentrations of crocidolite fibres found had no obvious source and were thought to be the result of background contamination. Similar concentrations were found in the Turkish sheep.

The morphology of the tremolite fibres recovered from sheep lungs and human lungs was compared with chrysotile fibres from human lungs (chrysotile in sheep lungs was virtually identical) and with crocidolite from South Africa. Distribution of fibre size (fig 3) shows that tremolite is found in a form that includes long thin fibres and thus resembles crocidolite.

Our most striking findings, however, were the num-
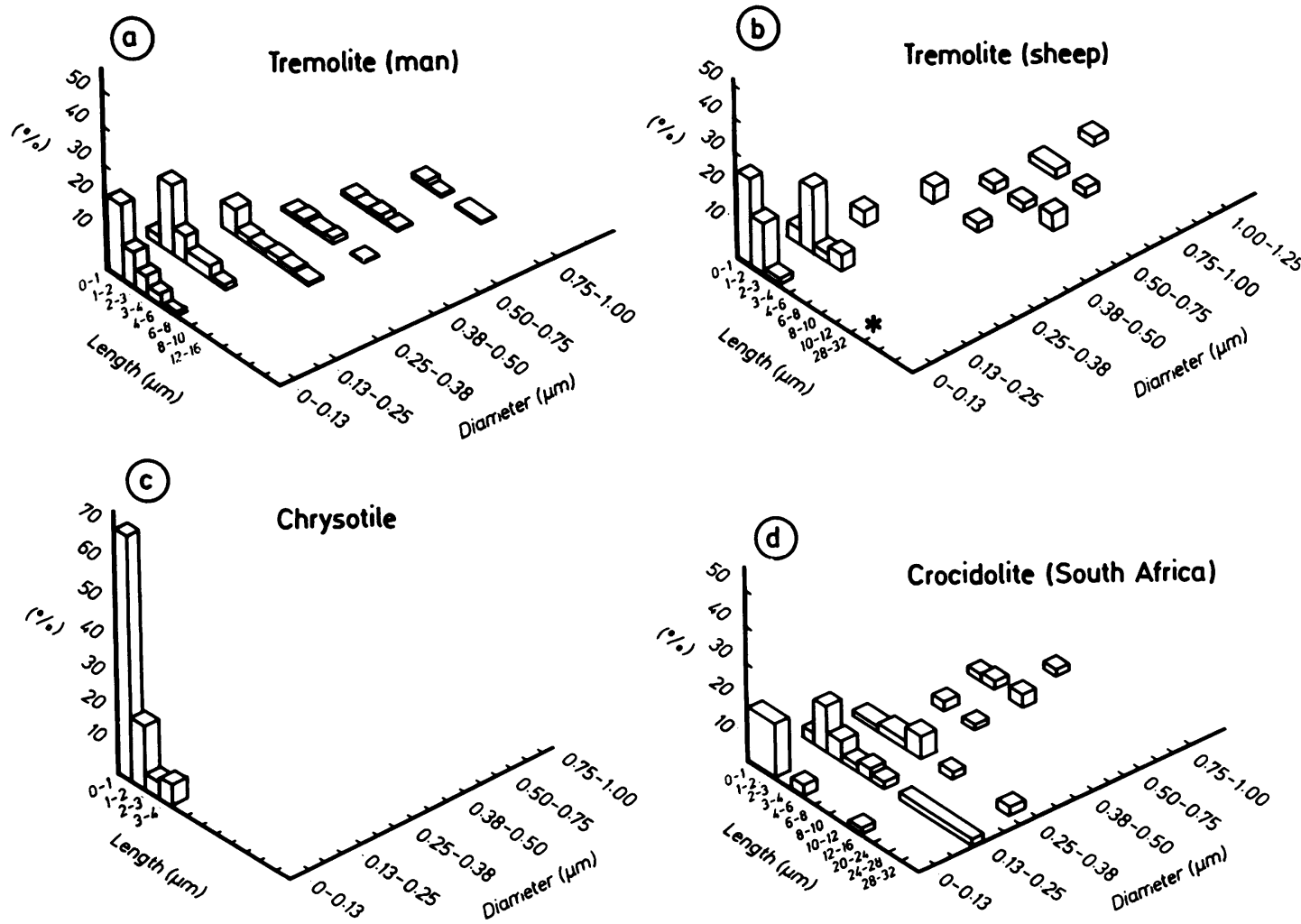

Fig 3 Fibre size distribution of: (a) tremolite fibres recovered from human lung (case 1); (b) tremolite fibres recovered from sheep lung (Cyprus); (c) chrysotile fibres recovered from human lung (case 1); and (d) crocidolite fibres in South Africa. 
ber and distribution of cases. Two of our cases should probably be excluded, case 8 because the diagnosis is still in doubt and case 14 because he had opportunity for exposure to asbestos in South Africa. The remaining 12 cases contained seven in whom the diagnosis has been confirmed by a panel of pathologists. Of these 12 cases, only five were asbestos miners. Three were miners' wives and two were residents with only environmental exposure. In the remaining two cases there have been no reports of apparent exposure. This distribution suggests that the mine is not the major source of disease, particularly as mine workers, with access to regular chest radiography, are more likely to have their disease diagnosed than villagers. Berry, in a recent review of mesothelioma that could be attributed without doubt to exposure to commercial grade chrysotile, found only 10 published cases. ${ }^{12}$ Thus the number of cases found on Cyprus suggests that either their chrysotile is behaving differently or, as we suspect from the amount of tremolite present in both human and sheep lungs, there is appreciable amphibole present.

The results of this survey to date suggest that exposure to tremolite, which contaminates chrysotile ore and occurs naturally in Cyprus, may have a role in the occurrence of cases of pleural mesothelioma reported from the island. This emphasises the importance of analysing fibres retained within the lung. These findings have begun further worldwide investigations into the biological importance of tremolite contamination of mineral ores and agricultural soils.

We are most grateful to Dr P Stavrinos for pathological material, $\mathbf{R}$ Mitha for mineralogical data, and Mrs S Price for typing the manuscript. We also thank the International Agency for Research on Cancer for financial support.

\section{References}

1 Wagner JC, Sleggs CA, Marchand P. Diffuse pleural mesothelioma and asbestos exposure in North Western Cape Province. Br J Ind Med 1970;17:260-71.

2 Hobbs MST, Woodward SD, Murphy B, Musk AW, Elder JE. The incidence of pneumoconiosis, mesothelioma and other respiratory cancer in men engaged in mining and milling crocidolite in Western Australia. In: Wagner JC, ed. Biological effects of mineral fibres. Lyon: International Agency for Research on Cancer 1980:615-25. (IARC Scientific Publication No 30.)

3 Acheson ED, Gardner MJ, Winter PD, Bennett C. Cancer in a factory using amosite asbestos. Int J Epidemiol 1984;13:3-10.

4 Pooley FD, Clark NJ. Quantitative assessment of inorganic fibrous particulates in dust samples with an analytical transmission electron microscope. Ann Occup Hyg 1979;22:253-71.

5 Gibbs GW. Qualitative aspects of dust exposure in the Quebec asbestos mining and milling industry. In: Walton WH, ed. Inhaled particles 3. Proceedings of the British Occupational Hygiene Society symposium. London: Unwin, 1970:783-99.

6 Kleinfeld M, Messite J, Zaki MH. Mortality experiences among talc workers: a follow-up study. J Occup Med 1974;16:345-9.

7 Pooley FD. An examination of the fibrous mineral content of asbestos lung tissue from the Canadian chrysotile mining industry. Environ Res 1976;12:281-98.

8 Churg A, Wiggs B, Depaoli L, Kampe B, Stevens B. Lung asbestos content in chrysotile workers with mesothelioma. Am Rev Respir Dis 1984;130:1042-5.

9 Wagner JC, Chamberlain M, Brown RC, et al. Biological effects of tremolite. Br J Cancer 1982;45:352-60.

10 Wilson RAM, Ingham FT. The geology of the XerosTroodos area with an account of the mineral resources. Margate: Eyre and Spottiswoode, 1959. (Geological Survey Department, Cyprus. Memoir No 1.)

11 Baris I, Simonato L, Artvinli M, et al. Epidemiological and environmental evidence of the health effects of exposure to erionite fibres: a four years study in the Cappadocian region of Turkey. Int J Cancer 1987; 39:10-7.

12 Berry G. Epidemiology conclusions. In: Wagner JC, ed. Monograph on the biological effects of chrysotile. Philadelphia: Lippincott. (In press.) 